\title{
Inhibition of Dopamine and Norepinephrine Reuptake Produces Additive Effects on Energy Balance in Lean and Obese Mice
}

\author{
Sonja K Billes' and Michael A Cowley*,' \\ 'Division of Neuroscience, Oregon National Primate Research Center, Oregon Health and Science University, Beaverton, OR, USA
}

\begin{abstract}
Although originally developed as an antidepressant, long-term bupropion (BUP) treatment was recently shown to cause 5-8\% weight loss over placebo in clinical trials with obese adults. BUP's antidepressant properties probably stem from its ability to increase extracellular brain dopamine (DA) and norepinephrine (NE) levels by inhibiting their reuptake, although the mechanism of BUP-induced weight loss is unknown. Consequently, the acute effects of DA and NE reuptake inhibition on energy homeostasis were determined by measuring food intake and body weight in mice following peripheral (intraperitoneal (i.p.)) administration of either BUP, a selective DA (GBR I2783), or a selective NE (nisoxetine (NIS)) reuptake inhibitor. BUP, GBRI2783, and NIS all dose-dependently decreased acute food intake in fasted lean mice. The ability of BUP to decrease food intake was independent of its ability to cause a temporary increase in locomotor activity. The inhibitory effects of acute GBRI2783 and NIS on short-term food intake were additive. Subchronic (via miniosmotic pump) administration of GBRI2783 and NIS produced a transient nonadditive effect on food intake, but produced an additive reduction in body weight (8-10\%). Because obesity can affect catecholaminergic signaling, we determined the effects of i.p. BUP, GBRI 2783, and NIS on short-term food intake in obese mice. Acute BUP, GBR I2783, and NIS dose-dependently reduced acute food intake, and the additive effect of GBRI2783 and NIS on acute food intake was preserved in obese mice. These results demonstrate that combined DA and NE reuptake inhibition produces additive effects on energy balance in lean and obese mice on both standard and high-fat diet, providing a foundation for further research on the effects of BUP and similar compounds on energy balance in mice. Neuropsychopharmacology (2007) 32, 822-834. doi: I0. 1038/sj.npp. I 30 I I55; published online 12 July 2006
\end{abstract}

Keywords: antidepressant; bupropion; reuptake inhibitor, food intake; body weight; obesity

\section{INTRODUCTION}

Bupropion (BUP) is an atypical antidepressant currently approved for the treatment of depression (Wellbutrin ${ }^{\circledR}$ ) and as an aid in smoking cessation $\left(Z_{y b a n}{ }^{\mathbb{R}}\right)$ (Ascher et al, 1995; Hughes et al, 2004). BUP has also recently been demonstrated to produce a significant $5-8 \%$ weight loss in clinical trials with obese patients (Gadde et al, 2001; Anderson et al, 2002; Jain et al, 2002); however, the mechanism of BUP-induced weight loss is unknown.

BUP inhibits reuptake of the catecholamines dopamine (DA) and norepinephrine (NE) through blockade of the dopamine (DAT) and norepinephrine reuptake transporters (NET) (Ascher et al, 1995; Hoffman, 2001; Stahl et al, 2004). These transporters are generally located on the presynaptic cell membrane and serve as the primary mechanism for clearance of these catecholamines (Eisenhofer, 2001). By

* Correspondence: Dr MA Cowley, Division of Neuroscience, Oregon National Primate Research Center, Oregon Health and Science University, 505 NW 185th Avenue, Beaverton, OR 97006, USA, Tel: + I 503533 422 I, Fax: + I 503690 5384, E-mail: cowleym@ohsu.edu Received 27 March 2006; revised 6 June 2006; accepted 7 June 2006 Online publication: 8 June 2006 at http://www.acnp.org/citations/ Npp06080606020 I/default.pdf blocking the removal of synaptic DA and NE, acute peripheral treatment with BUP produces transient changes in extracellular DA and $\mathrm{NE}$ concentrations in the brain (Nomikos et al, 1992), and may also alter the activity of the neurons that release DA and NE (Ascher et al, 1995; Paladini et al, 2003).

DA is essential for normal feeding behavior; DA-deficient mice do not eat in spite of hypothalamic changes that indicate they sense a nutritional deficit (Zhou and Palmiter, 1995). In contrast, NE-deficient mice are slightly hyperphagic (Thomas and Palmiter, 1997). Hypothalamic infusion of DA or NE can either increase or decrease food intake, depending on the location of infusion (Yang et al, 1997; Wellman, 2005). As both DA and NE are involved in the regulation of energy homeostasis (Wellman, 2005), BUP's unique effect on body weight may be owing to its combined effects on both dopaminergic and noradrenergic signaling.

The therapeutic potential for treatments that affect dopaminergic and noradrenergic signaling is apparent in that DA receptor agonists reduce elevated levels of the orexigenic neuropeptide, neuropeptide Y (NPY), in the hypothalamus and normalizes the hyperphagia, body weight gain, and hyperglycemia observed in obese $o b / o b$ mice (Bina and Cincotta, 2000). In addition, the anorectic 
effects of the only centrally acting Food and Drug Administration (FDA)-approved weight-loss drug, sibutramine (an NE and serotonin reuptake inhibitor), are abolished when rats are pretreated with an $\alpha_{1}$-adrenoceptor antagonist (Jackson et al, 1997). Combined DA and NE reuptake inhibition (as with BUP) may therefore have an increased effect on energy homeostasis, owing to an additive or synergistic effect on these two systems.

Acute BUP increases energy expenditure in rodents (by increasing thermogenesis and $\mathrm{VO}_{2}$ consumption) and appears to decrease food intake; however, the efficacy with which BUP inhibits food intake in rats is variable (Zarrindast and Hosseini-Nia, 1988; Liu et al, 2004). Reports that rats do not make significant quantities of hydroxybupropion, a BUP metabolite that possesses affinity for both the DA and NE reuptake transporters (Welch et al, 1987; Bondarev et al, 2003), suggest that rats may not be an optimal model for investigating the mechanism of BUPinduced weight loss. Although mice make the same three major bioactive BUP metabolites made by humans (Welch et al, 1987), the effects of BUP on energy balance in mice have not yet been reported.

The aim of this study was to investigate how DA and NE reuptake inhibition affects energy balance in lean and obese mice. First, we examined the effects of acute administration of BUP on short-term food intake and locomotor activity in lean mice, and examined the effects of selective DA and NE reuptake inhibitors on food intake. We then assessed how acute and subchronic coadministration of selective DA and NE reuptake inhibitors affects food intake and body weight in lean mice. Finally, we compared the effects of acute DA and NE reuptake inhibition on energy balance in lean and obese mice on a high-fat diet.

\section{MATERIALS AND METHODS}

\section{Animal Care and Housing}

All animal procedures were approved by the Oregon National Primate Research Center Institutional Animal Care and Use Committee. Adult male C57BL/6J mice (Jackson Labs, Bar Harbor, ME) were individually housed under a $12 \mathrm{~h} \mathrm{light/dark}$ cycle and constant temperature $\left(23^{\circ} \mathrm{C}\right)$. Food and water were available ad libitum, except where noted. Surgical procedures were performed under isoflurane anesthesia and using aseptic surgical procedures. Mice were maintained on standard chow, except where noted (Purina Lab Chow \#5001; $3.34 \mathrm{kcal} / \mathrm{g}$ of energy, $59.8 \%$ carbohydrate, $28.0 \%$ protein, and $12.1 \%$ fat).

\section{Drugs}

All drugs were freshly prepared on the day of use. BUP (Sigma, St Louis, MO) was dissolved in sterile nonpyrogenic $0.9 \% \mathrm{NaCl}$. Nisoxetine (NIS) (Tocris, Ellisville, MO) was also dissolved in sterile saline, except during coadministration studies, when both NIS and GBR12783 (GBR; Tocris) were dissolved in $10 \%$ dimethyl sulfoxide and sterile saline (vehicle). Drugs were administered intraperitoneally (i.p.) in a volume of $0.1 \pm 0.02 \mathrm{ml}$ (according to body weight) for feeding tests. Control mice received vehicle in a corresponding volume.

\section{Behavioral Testing Procedure}

Individually housed mice were habituated to the behavioral testing procedure by daily i.p. injection of $0.1 \mathrm{ml}$ sterile saline and $16 \mathrm{~h}$ (overnight) fasting every third day for at least 1 week before treatment. All mice were randomly distributed (according to body weight) to the treatment groups. On the morning of the testing day, fasted mice were injected with drug or vehicle, and given six previously weighed food pellets. Food was weighed at 1, 2, 4, 8, and $24 \mathrm{~h}$ postinjection. One week was allowed between testing sessions. Because BUP can cause seizures at high doses and dopaminergic drugs can affect locomotor activity, animals were closely monitored for the first few hours following drug injection and any adverse side effects were noted.

\section{Telemetric Transponder Implantation and Activity Measurement}

To explore the specific effect of acute BUP administration on locomotor activity, mice were implanted interscapularly with a PDT-4000 E-mitter sensor (MiniMitter, Sun River, OR). Mice were allowed 1-week recovery before behavioral feeding studies commenced. Three separate feeding experiments were performed (as described above), each with a different dose of BUP. For each experiment, 16 mice were divided into two weight-matched groups, one receiving vehicle injection and the treatment group receiving 10,20 , or $40 \mathrm{mg} / \mathrm{kg}$ BUP. Locomotor activity measurements were taken every $6 \mathrm{~min}$ using VitalView and Actiview software (MiniMitter).

\section{Subchronic Drug Administration Studies}

Adult male mice were divided into four weight-matched groups. Subcutaneous Alzet ${ }^{\circledR}$ minipumps (model 1007D and 2001; Durect Corporation, Cupertino, CA) containing drug or vehicle were implanted via a small incision in the skin behind the scapulae. The incision was closed with wound clips and mice were monitored daily. To minimize possible drug interaction effects, all mice were implanted with two minipumps. One minipump contained either NIS or NIS vehicle $(90 \%$ sterile nonpyrogenic saline $+10 \%$ dimethyl sulfoxide), and the other contained GBR or GBR vehicle ( $50 \%$ sterile $\mathrm{H}_{2} \mathrm{O}+50 \%$ dimethyl sulfoxide). Minipumps delivered the following doses of drug: NIS $(1.5 \mathrm{mg} /$ $\mathrm{kg} / \mathrm{h}), \mathrm{GBR}(2.5 \mathrm{mg} / \mathrm{kg} / \mathrm{h}), \mathrm{NIS}(1.5 \mathrm{mg} / \mathrm{kg} / \mathrm{h})+\mathrm{GBR}(2.5 \mathrm{mg} /$ $\mathrm{kg} / \mathrm{h})$, or vehicle. These doses were based on a pilot experiment ( $n=2$ /group), where the same dose of NIS was administered in combination with a higher dose of GBR $(3.75 \mathrm{mg} / \mathrm{kg} / \mathrm{h})$. Mice that received GBR $(3.75 \mathrm{mg} / \mathrm{kg})$ exhibited stereotypy (by severely overgrooming) and were killed. Because stereotypy is a side effect of dopaminergic drugs, the dose of GBR was decreased to $2.5 \mathrm{mg} / \mathrm{kg} / \mathrm{h}$ and no stereotypy was observed at this dose. Food intake and body weight were recorded daily.

\section{Generation of Obese (Diet-Induced Obese, DIO) Mice}

Eight-week-old male mice were kept on a high-fat diet (Rodent Chow \#D12451, Research Diets Inc., New Brunswick, NJ; $4.75 \mathrm{kcal} / \mathrm{g}$ of energy, $35.0 \%$ carbohydrate, $20.0 \%$ protein, and $45.0 \%$ fat) for 20 weeks. After 20 weeks, DIO 
mice are characterized by increased body weight and fat deposits, and reduced central leptin sensitivity (Lin et al, 2000). Age-matched lean mice were used as a control. Because all behavioral studies on obese mice were conducted by measuring intake of high-fat diet, lean agematched (control) mice were also put on a high-fat diet just before feeding tests. The novel high-fat diet causes a temporary increase in food intake, so feeding tests were not begun until daily food intake stabilized (about 1 week).

\section{Statistical Analysis}

Data sets were analyzed using Prism Software (Graph-Pad Software, San Diego, CA) to generate sigmoidal doseresponse curves, $\mathrm{ID}_{50} \mathrm{~s}$ (the estimated doses that result in $50 \%$ inhibition of food intake), area under the curve (AUC), and to determine statistical significance. One-way analysis of variance (ANOVA) and Tukey's multiple comparison post-tests were used to determine significant differences between treatment groups. Activity measurements were analyzed by comparing AUC values for vehicle and treatment groups and data were analyzed using one-way ANOVA (as above). For drug coadministration studies, two-way ANOVA was used to identify significant drug interactions (additivity/synergism) and independent main effects. A $P$-value $<0.05$ was considered significant. Data are expressed as mean \pm SEM.

\section{Analysis of Drug Additivity/Synergy}

Drug additivity occurs when the response to both drugs equals the sum of the individual responses to each drug.
Synergism occurs when the response to both drugs is significantly greater than the sum of their individual responses and the null hypothesis for synergism is an additive effect or the lack of a drug interaction. Isobolographic analysis and two-way ANOVA were both used to analyze feeding data in lean mice; two-way ANOVA was used to determine the effects of NIS and GBR for all other coadministration studies. An isobologram is constructed by plotting different doses of drug that produce the same effect (in this case, the doses of drug that produced the same fractional reduction in food intake) (Wessinger, 1986). For isobolographic analysis, doses of NIS and GBR that reduced food intake by about $50 \%$ were plotted and compared to the combined doses of these drugs that reduced food intake by $50 \%$. For two-way ANOVA analysis, data (food intake or body weight) were plotted using Prism Software (Graph-Pad Software). The F-statistic for an interaction effect in a two-way ANOVA is mathematically comparable to testing the null hypothesis (for a review, see Slinker, $1998)$; therefore, a significant interaction between drugtreated animals $(P<0.05)$ was considered indicative of a synergistic interaction (Slinker, 1998).

\section{RESULTS}

Acute Inhibition of DA and NE Reuptake by BUP Causes a Dose-Dependent Reduction in Food Intake in Lean Mice

BUP $(5,10,20,40$, or $80 \mathrm{mg} / \mathrm{kg}$ i.p.) dose-dependently inhibited 1-h food intake in $16 \mathrm{~h}$ food-deprived mice (Figure 1a; $n=7 /$ group). The $\mathrm{ID}_{50}$ for $\mathrm{BUP}$ was $50 \mathrm{mg} / \mathrm{kg}$
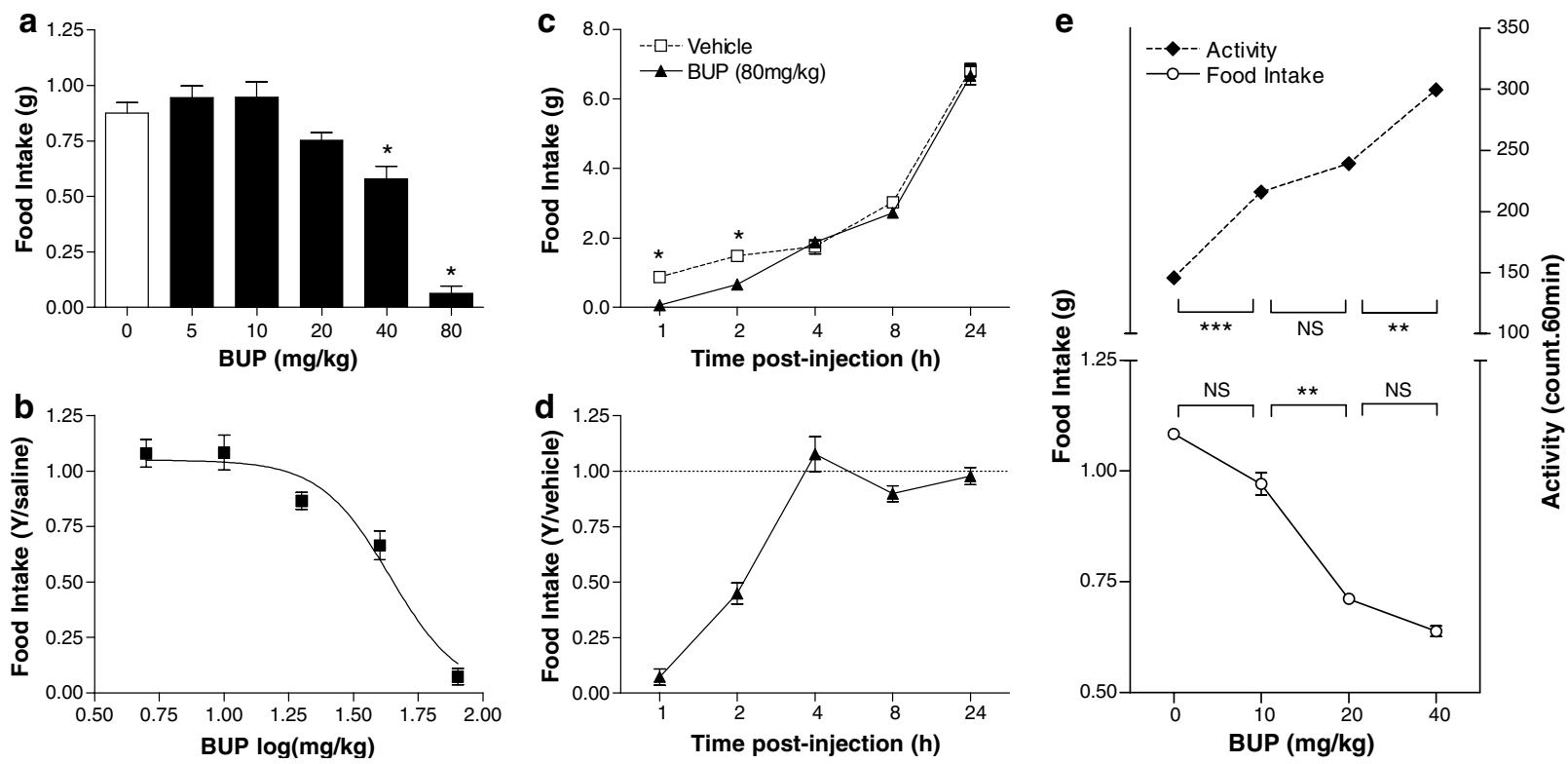

Figure I Acute combined inhibition of DA and NE reuptake by BUP produces a dose-dependent reduction in I h food intake in lean mice. Overnight food-deprived mice were treated with BUP (5, 10, 20,40, or $80 \mathrm{mg} / \mathrm{kg}$ i.p.) or vehicle and their subsequent food intake was recorded. (a) BUP (40 and $80 \mathrm{mg} / \mathrm{kg}$ ) significantly reduced I h food intake compared to vehicle (*P $<0.05)$. (b) Dose-response curve for reduction in I h food intake by BUP $\left(R^{2}=0.87\right)$. (c) Time course for $80 \mathrm{mg} / \mathrm{kg} B \cup P$ and vehicle. Food intake differed significantly from vehicle at I and $2 \mathrm{~h}$ postinjection $(* * P<0.0 \mathrm{I}$ ). (d) Time course for $80 \mathrm{mg} / \mathrm{kg}$ normalized to vehicle ( $n=7 / \mathrm{group}$ ). (e) BUP caused a dose-dependent increase in locomotor activity that was independent of food intake ( $n=8 /$ group). Larger doses of BUP that caused relative increases in activity $(0-10$ and $20-40 \mathrm{mg} / \mathrm{kg})$ did not produce a comparable decrease in intake. Similarly, increasing the BUP dose from 10 to $20 \mathrm{mg} / \mathrm{kg}$ caused a significant reduction in food intake from $10 \mathrm{mg} / \mathrm{kg}$, but no significant change in activity $(* * P<0.01$ and $* * * P<0.001)$. 
(Figure 1b). The effect of BUP on feeding was transient; cumulative intake of BUP-treated mice was similar to vehicle-treated animals by $4 \mathrm{~h}$ postinjection (and all subsequent time points) for all doses of BUP (Figure 1c and d). In pilot studies, a dose of $160 \mathrm{mg} / \mathrm{kg}$ appeared to produce seizures in some animals, as has been reported for high doses of this drug (Davidson, 1989). Therefore, $80 \mathrm{mg} /$ $\mathrm{kg}$ was chosen for the highest dose to be tested; this dose did not produce seizures in any animals.

\section{BUP Produces Independent Effects on Food Intake and Locomotor Activity}

Food intake decreased significantly from control only with the 20 and $40 \mathrm{mg} / \mathrm{kg}$ doses and only at $1 \mathrm{~h}$ postinjection (Figure 1e; $n=8$ /group). All doses of BUP $(10,20$, and $40 \mathrm{mg} / \mathrm{kg}$ ) significantly increased activity from control at $1 \mathrm{~h}$ postinjection (Figure 1e; $n=8$ /group) and activity returned to baseline $2-4 \mathrm{~h}$ postinjection. The increase in activity caused by peripheral BUP was dose-dependent. The effects of BUP on food intake and locomotor activity are independent, such that increasing doses of BUP that caused an incremental increase in activity did not also significantly decrease food intake (0-10 and $20-40 \mathrm{mg} / \mathrm{kg}$ ). Likewise, the incremental decrease in food intake between the 10 and $20 \mathrm{mg} / \mathrm{kg}$ doses was not correlated with a simultaneous increase in activity.

\section{Selective Inhibition of DA Reuptake by GBR12783 Dose-Dependently Reduces Food Intake in Lean Mice}

To determine whether DA reuptake inhibition contributes to the hypophagic response to BUP, the effect of a selective DA reuptake inhibitor, GBR12783 (GBR), on food intake was tested (Bonnet and Costentin, 1986). GBR $(1,2.5,6,16$, or $40 \mathrm{mg} / \mathrm{kg}$ ) or vehicle was administered i.p. to overnight $(16 \mathrm{~h})$ food-deprived mice. GBR reduced food intake in a dose-dependent manner (Figure 2a; $n=6$ /group). The extrapolated $\mathrm{ID}_{50}$ for GBR at $1 \mathrm{~h}$ was $14 \mathrm{mg} / \mathrm{kg}$ (Figure $2 \mathrm{~b}$ ). Acute administration of GBR had a transient effect on feeding; the reduction in food intake by GBR was absent by $4 \mathrm{~h}$ postinjection (Figure $2 \mathrm{c}$ and $\mathrm{d}$ ). Anecdotal observation revealed that large doses of GBR $(40 \mathrm{mg} / \mathrm{kg})$ increased locomotor activity but no stereotopy or abnormal locomotor behaviors were observed.

\section{Selective Inhibition of NE Reuptake by NIS Dose-Dependently Reduces Food Intake in Lean Mice}

To determine whether inhibition of NE reuptake contributed to the reduction in feeding caused by BUP, the effect of NIS, a selective NE reuptake inhibitor (Cheetham et al, 1996), was determined by monitoring food intake in NIS- or vehicle-treated animals. Peripheral NIS $(0.1,0.5,2.5,13$, and $63 \mathrm{mg} / \mathrm{kg}$ ) produced a dose-dependent decrease in 1-h food intake (Figure 3a; $n=6$ /group). The extrapolated $\mathrm{ID}_{50}$ was $5 \mathrm{mg} / \mathrm{kg}$ at $1 \mathrm{~h}$ (Figure $3 \mathrm{~b}$ ). The reduction in feeding caused by peripheral NIS persisted longer than $8 \mathrm{~h}$, but was absent $24 \mathrm{~h}$ postinjection (Figure $3 \mathrm{c}$ and $\mathrm{d}$ ).
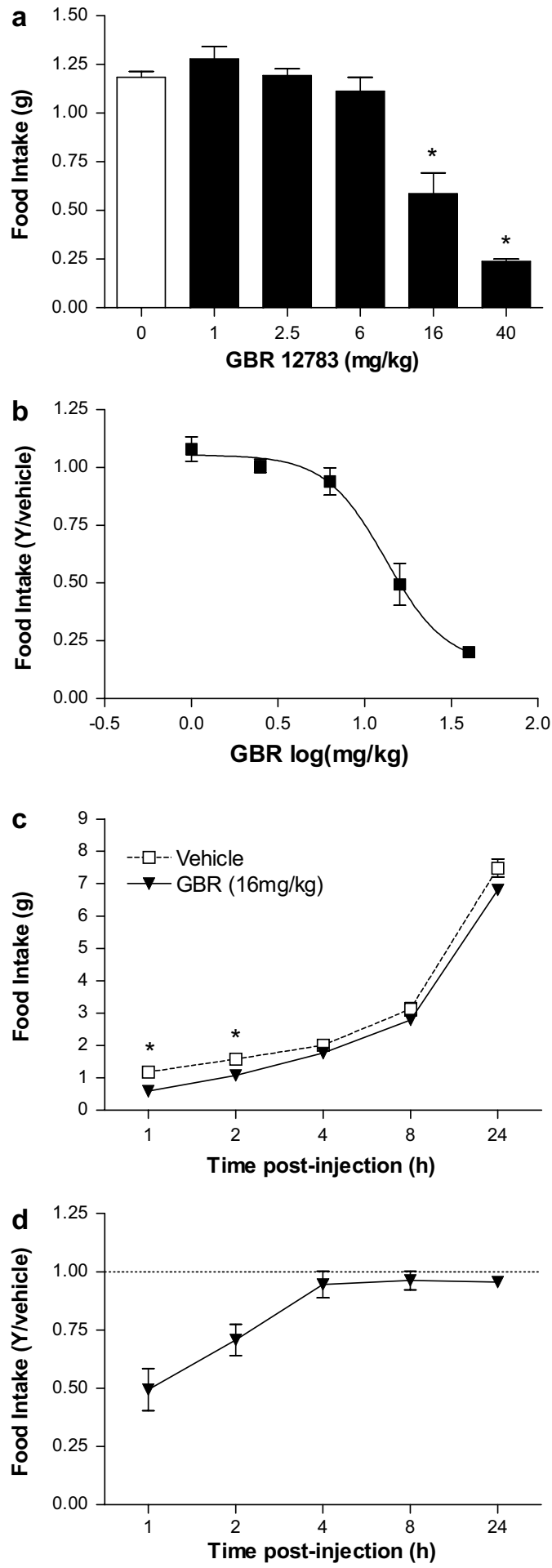

Figure 2 Acute selective inhibition of DA reuptake with GBRI2783 produces a dose-dependent reduction in $\mathrm{Ih}$ food intake in lean mice. Sixteen-hour food-deprived mice were treated with GBR (I, 2.5, 6.3, 16, and $40 \mathrm{mg} / \mathrm{kg}$ i.p.) or vehicle and their subsequent food intake was recorded. (a) GBR (16 and $40 \mathrm{mg} / \mathrm{kg}$ ) significantly reduced I h food intake $(P<0.05)$. (b) Dose-response curve for reduction in $1 \mathrm{~h}$ food intake by GBR $\left(R^{2}=0.85\right)$. (c) Time course for $16 \mathrm{mg} / \mathrm{kg}$ GBR and vehicle. Food intake differed significantly from vehicle at I h postinjection $(P<0.05)$. (d) Time course for GBR $(16 \mathrm{mg} / \mathrm{kg})$ normalized to vehicle ( $n=6 /$ group). 

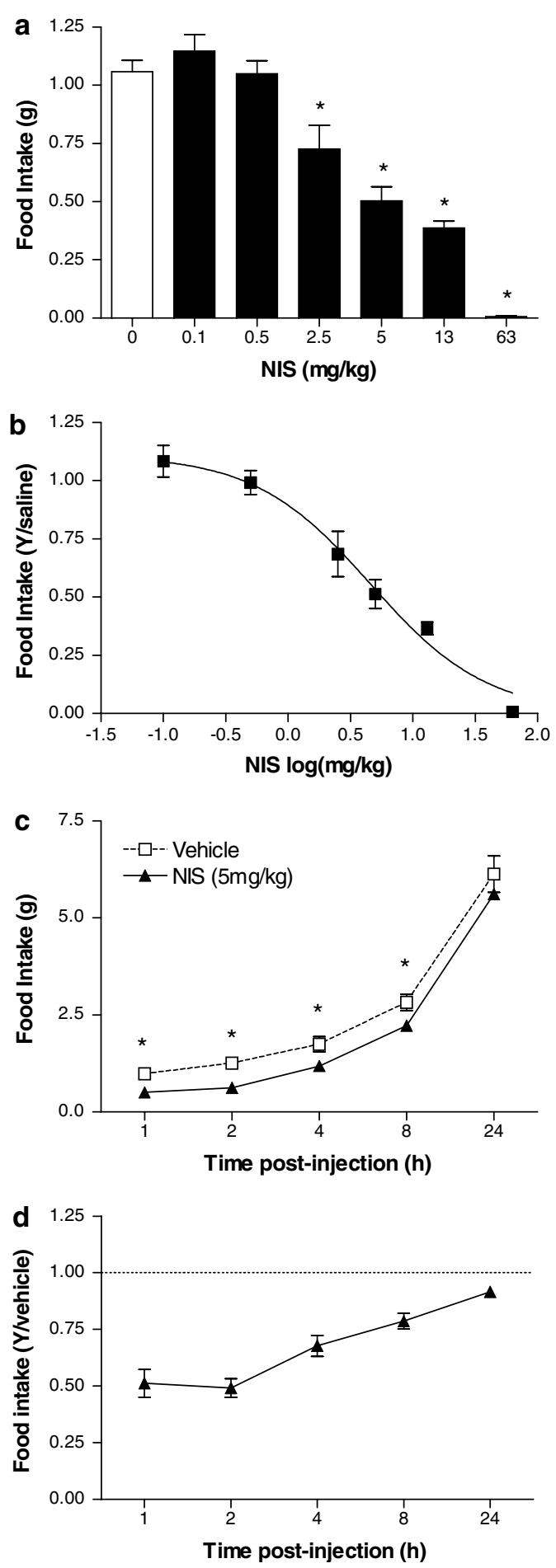

Figure 3 Acute selective inhibition of NE reuptake by NIS produces a dose-dependent reduction in I $\mathrm{h}$ food intake in lean mice. Sixteen-hour food-deprived mice were treated with NIS $(0.1,0.5,2.5,5,13$, and $63 \mathrm{mg} / \mathrm{kg}$ i.p.) or vehicle and their subsequent food intake was recorded. (a) NIS $(2.5,5,13$, and $63 \mathrm{mg} / \mathrm{kg})$ significantly reduced I h food intake compared to vehicle $(P<0.05)$. (b) Dose-response curve for reduction in I h food intake by NIS $\left(R^{2}=0.89\right)$. (c) Time course for $5 \mathrm{mg} / \mathrm{kg}$ NIS and vehicle. Food intake differed significantly from vehicle at $\mathrm{I}, 2,4$, and $8 \mathrm{~h}$ postinjection $(P<0.05)$. (d) Time course for NIS $(5 \mathrm{mg} / \mathrm{kg})$ normalized to vehicle ( $n=6 /$ group).

Acute Coadministration of DA and NE Reuptake Inhibitors has an Additive Effect on Food Intake in Lean Mice

Because acute inhibition of DA and NE reuptake both reduced short-term food intake, we tested whether simultaneous administration of GBR and NIS would produce an additive or synergistic effect on food intake. Combined administration of low drug doses that have minimal independent effects on food intake enables detection of a larger effect caused by a drug interaction. Thus, low doses of NIS and GBR were administered for coadministration studies. To determine how slight variations in dose might affect possible drug interactions, we administered two doses of GBR. The $\mathrm{ID}_{15}$ dose of NIS $(3.5 \mathrm{mg} / \mathrm{kg})$, and the $\mathrm{ID}_{15}(\mathrm{GBR} 1=4.5 \mathrm{mg} / \mathrm{kg})$ and $\mathrm{ID}_{25}$ $(\mathrm{GBR} 2=7.5 \mathrm{mg} / \mathrm{kg})$ doses of GBR were extrapolated from the dose-response curves for each drug (Figures $2 \mathrm{~b}$ and $3 \mathrm{~b})$. The $\mathrm{ID}_{15}$ dose of NIS was administered alone or in combination with the $\mathrm{ID}_{15}$ or $\mathrm{ID}_{25}$ doses of GBR (Figure 4a-f).

At $1 \mathrm{~h}$ postinjection, NIS $(3.5 \mathrm{mg} / \mathrm{kg})$ and GBR $1(4.5 \mathrm{mg} /$ $\mathrm{kg}$ ) independently reduced short-term food intake and caused a significantly greater decrease in food intake when administered together (Figure $4 \mathrm{a} ; n=21$ /group). NIS $(3.5 \mathrm{mg} / \mathrm{kg})$ reduced $1 \mathrm{~h}$ food intake by $17 \%$ and GBR $1(4.5 \mathrm{mg} / \mathrm{kg})$ reduced $1 \mathrm{~h}$ food intake by $13 \%$ relative to control (Figure 4b). The predicted additive effect of combined administration of these drugs would be $30 \%$ inhibition. The actual reduction in food intake by coadministration of NIS and GBR1 was $34 \%$. The comparable predicted additive and actual effects implies that NIS and GBR1 have an additive effect on food intake. NIS + GBR2 also produced a greater reduction in food intake than NIS or GBR2 alone that was absent by $4 \mathrm{~h}$ (Figure $4 \mathrm{~d}$ and $\mathrm{f}$ ). The predicted additive effect for NIS and GBR2 would be $41 \%$ inhibition of $1 \mathrm{~h}$ food intake (Figure 4e). The actual effect of combined administration of NIS and GBR2 was a 51\% inhibition of food intake, suggesting that NIS and GBR2 might interact in a synergistic manner.

To further explore this possibility, isobolographic analysis was performed for NIS and GBR2 (Figure 5a). The combined doses of NIS and GBR that produced a 50\% reduction in food intake fell on the additivity line, suggesting that acute NIS and GBR2 had only an additive effect on food intake. Two-way ANOVA analysis of mean $1 \mathrm{~h}$ food intake for NIS and GBR2 supported this finding (Figure 5b; $P=0.205$, no significant interaction). NIS and GBR2 had significant independent effects on food intake that were additive $(P<0.001$ for both drugs at 1 and $2 \mathrm{~h}$ postinjection). As expected, two-way ANOVA analysis of $1 \mathrm{~h}$ food intake following acute NIS and GBR1 also revealed no significant interaction (Figure $5 c ; P=0.490$ ), but a significant main effect of NIS and GBR1 at $1 \mathrm{~h}(P<0.001$ for both drugs). This analysis also revealed no significant interaction for NIS and GBR1 and for NIS and GBR2 at any other time points $(P>0.05$; data not shown). Because two-way ANOVA provides both a visual and statistical interpretation of the data, this was the primary method we used for interpreting future data obtained from drug coadministration. 

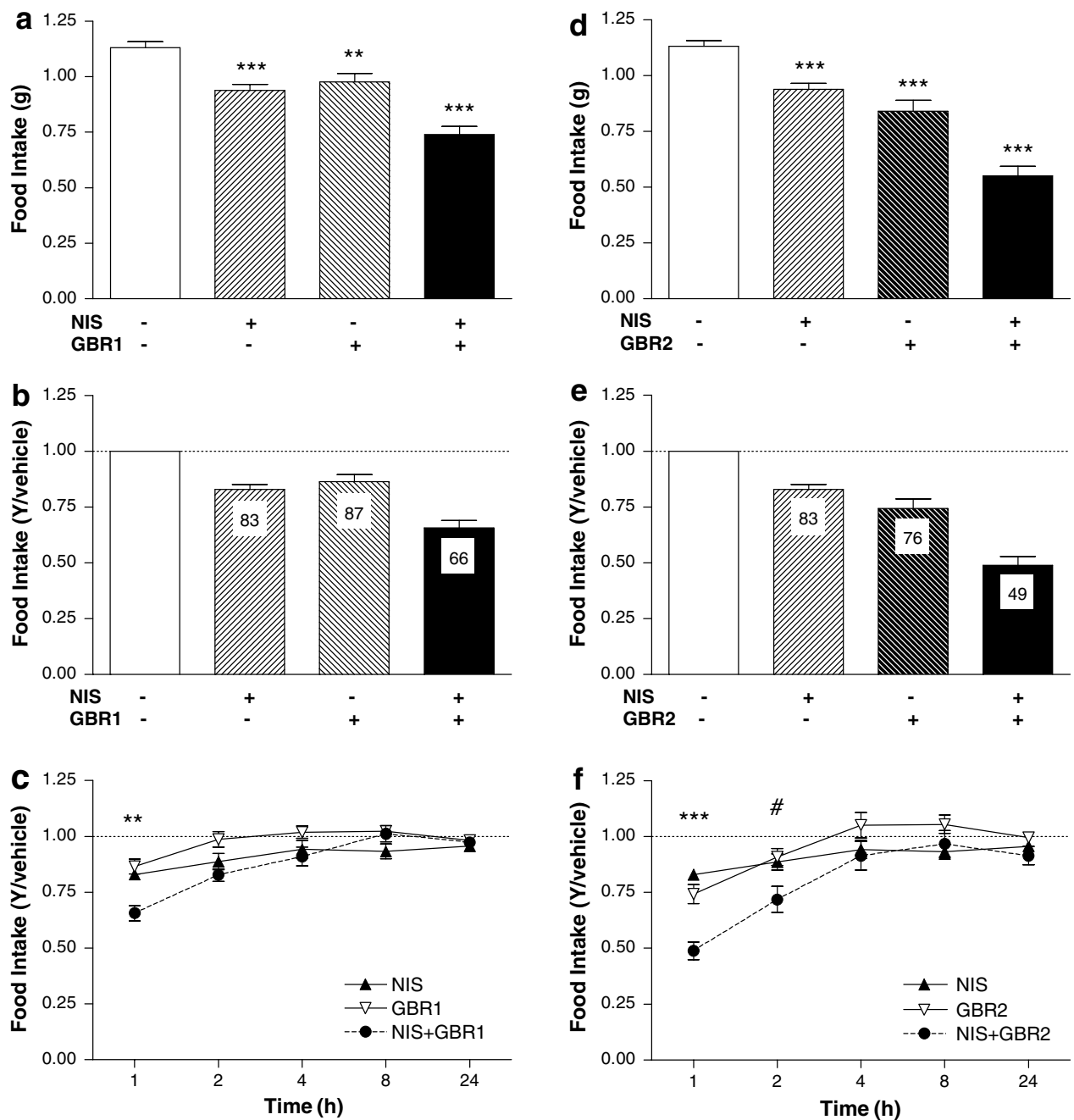

Figure 4 Acute inhibition of DA and NE reuptake reduces food intake in lean mice. (a-c) Sixteen-hour food-deprived mice were treated with NIS (3.5 mg/kg i.p.) or GBRI (4.5 mg/kg i.p.). (a) NIS, GBRI, and NIS + GBRI all produced a significant reduction in cumulative I h food intake compared to vehicle ( $n=2$ I/group). (b) One-hour food intake normalized to vehicle. Numbers in the column represent \% of control intake. (c) Time course for NIS, GBRI, and NIS + GBRI (normalized to vehicle). The reduction in food intake caused by NIS, GBRI, and NIS + GBRI was absent by $2 \mathrm{~h}$ postinjection $($ *** $P<0.0 \mathrm{I})$. (d-f) Food intake for mice treated with NIS $(3.5 \mathrm{mg} / \mathrm{kg}$ i.p.) or GBR2 (7.5 mg/kg i.p.). (d) NIS, GBR2, and NIS + GBR2 all significantly reduced food intake relative to vehicle $(n=2 \mathrm{I} /$ group). (e) One-hour food intake normalized to vehicle. Numbers in the column represent \% of control intake. ( $f$ ) Time course for NIS, GBR2, and NIS + GBR2 (normalized to vehicle). NIS or GBR2 caused a reduction in I h food intake only $(* * * P<0.00$ I), but NIS + GBR2 caused a reduction in I and $2 \mathrm{~h}$ food intake $\left({ }^{\#} P<0.0 \mathrm{I}\right)$.

\section{Subchronic DA and NE Reuptake Inhibition Produces an Additive Decrease in Body Weight in Lean Mice}

To determine how the effects of acute DA and NE reuptake inhibition on energy balance compare with the effects of continuous subchronic administration, NIS and GBR were administered for 1 week via mini-osmotic pump. Food intake differed significantly from vehicle $(n=4)$ in all three drug treatment groups (GBR, $n=4$; NIS, $n=4$; GBR + NIS, $n=3$ ) on the first day of drug infusion, but returned to control for the duration of the infusion (Figure 6a). Subchronic inhibition of DA or NE reuptake caused a small reduction in body weight for the duration of the infusion that returned to control levels after drug infusion (Figure 6b). Of the three drug treatments given subchronically (NIS, GBR, and NIS + GBR), only NIS + GBR caused significant weight loss compared to control on days 2-7 of drug infusion. On day 5, body weight of animals that received GBR + NIS was significantly reduced compared to animals that received only GBR or NIS (Figure 6c). By a loose definition, this could be interpreted as a synergistic interaction between the DA and NE reuptake inhibitors because neither the GBR- nor the NIS-treated animals differed significantly from control for the duration of the drug infusion. However, two-way ANOVA demonstrated that there was no statistically significant interaction between GBR and NIS on body weight on day 5 (Figure 6d; $P=0.483$ ) or any other day (data not shown). Instead, two-way ANOVA revealed that NIS and GBR both produced significant main effects on days 4 and $5(P<0.05$ for both NIS and GBR), indicating that NIS and GBR had significant independent effects on body weight that were additive. 

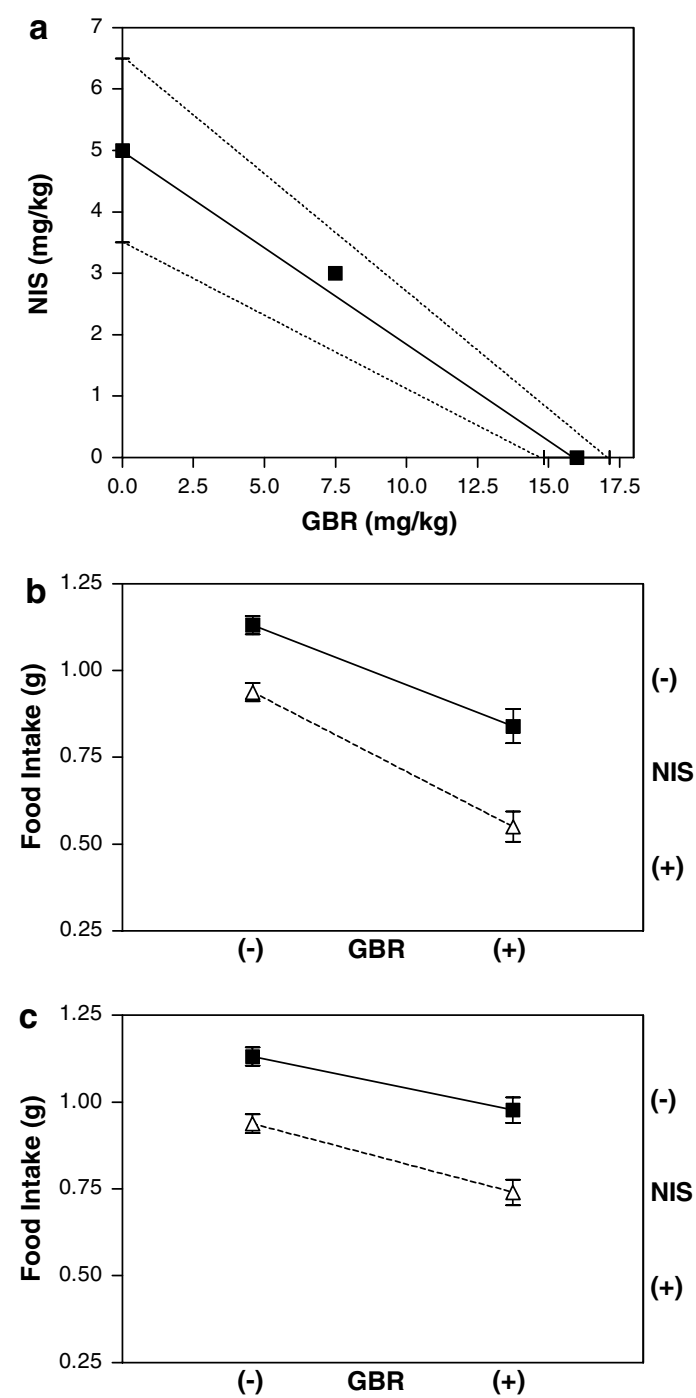

Figure 5 Acute combined inhibition of DA and NE reuptake produces an additive reduction in food intake in lean mice. (a) Isobologram depicting doses of NIS (5 mg/kg; $n=6), G B R(16 \mathrm{mg} / \mathrm{kg} ; n=6)$, and NIS + GBR2 $(\mathrm{NIS}=3.5 \mathrm{mg} / \mathrm{kg} ; \mathrm{GBR} 2=7.5 \mathrm{mg} / \mathrm{kg} ; n=2 \mathrm{l})$ that reduced food intake by approximately $50 \%$ from control. (b) Two-way ANOVA of I h food intake in lean mice treated with vehicle, NIS (3.5 mg/kg), GBR2 $(7.5 \mathrm{mg} / \mathrm{kg})$, or NIS + GBR2 revealed no significant interaction between NIS and GBR2 ( $P>0.05 ; n=21 /$ group). (c) Two-way ANOVA of I $h$ food intake in lean mice treated with vehicle NIS $(3.5 \mathrm{mg} / \mathrm{kg})$, GBRI $(4.5 \mathrm{mg} / \mathrm{kg})$, or NIS + GBRI revealed no significant interaction between NIS and GBRI $(P>0.05$; $n=21$ /group).

\section{Inhibition of DA and NE Reuptake Causes a Dose-Dependent Reduction in Food Intake in Obese Mice}

To determine whether DA and NE reuptake inhibitors decrease food intake in an obese rodent model, BUP, GBR, and NIS were administered to lean (control; $n=5$ /group) and obese (DIO; $n=7 /$ group) mice on a high-fat diet. Inhibition of DA and NE reuptake by acute (i.p.) injection of BUP $(10,50$, and $80 \mathrm{mg} / \mathrm{kg})$ caused a transient and dosedependent reduction in $1 \mathrm{~h}$ food intake in lean and obese mice with an $\mathrm{ID}_{50}$ of $41 \mathrm{mg} / \mathrm{kg}$ for both lean and obese mice (Figure $7 \mathrm{a}$ and $\mathrm{d}$ ). Acute inhibition of DA reuptake by GBR
$(1,2.5,6.3,14$, and $40 \mathrm{mg} / \mathrm{kg})$ transiently reduced intake of a high-fat diet in lean $\left(\mathrm{ID}_{50}=8 \mathrm{mg} / \mathrm{kg}\right)$ and obese $\left(\mathrm{ID}_{50}=7 \mathrm{mg} / \mathrm{kg}\right.$ ) mice (Figure $7 \mathrm{~b}$ and e). Inhibition of $\mathrm{NE}$ reuptake by NIS $(0.5,2.5,5,13$, and $30 \mathrm{mg} / \mathrm{kg})$ also caused a dose-dependent reduction in short-term food intake in lean and obese mice (Figure $7 \mathrm{c}$ and $\mathrm{f}$ ). The $\mathrm{ID}_{50}$ for NIS in obese mice was $5 \mathrm{mg} / \mathrm{kg}$, about the same as for lean mice on a standard diet; however, NIS was slightly less efficacious at reducing intake of a high-fat diet in lean mice $\left(\mathrm{ID}_{50}=\right.$ $9 \mathrm{mg} / \mathrm{kg}$ ).

\section{Acute Coadministration of DA and NE Reuptake Inhibitors has an Additive Effect on Food Intake in Obese Mice}

To determine whether DA and NE reuptake inhibitors have an additive effect on food intake in obese mice, NIS $(3.5 \mathrm{mg} /$ $\mathrm{kg})$, GBR $(7.5 \mathrm{mg} / \mathrm{kg})$, NIS + GBR, or vehicle were administered i.p. to $16 \mathrm{~h}$ food-deprived lean ( $n=9 /$ group) and obese ( $n=15$ /group) mice on a high-fat diet. Although GBR and NIS + GBR significantly reduced $1 \mathrm{~h}$ intake of high-fat diet in lean mice, NIS $(3.5 \mathrm{mg} / \mathrm{kg})$ had no effect at $1 \mathrm{~h}$ (Figure 8a) or any of the time points measured (data not shown). GBR $(7.5 \mathrm{mg} / \mathrm{kg})$ produced a $49 \%$ reduction in intake of a high-fat diet at $1 \mathrm{~h}$, and coadministration of NIS + GBR caused considerable (85\%) inhibition of $1 \mathrm{~h}$ food intake (Figure 8b). However, two-way ANOVA revealed no significant interaction between NIS and GBR on intake of a high-fat diet in lean mice at $1 \mathrm{~h}$ postinjection (Figure 8c; $P=0.116$ ) or at any other time points (data not shown), but instead indicated a significant effect of GBR on food intake $(P<0.001$ for $1,2,4$, and $8 \mathrm{~h}$ postinjection) but not for NIS $(P>0.05$; Figure $8 \mathrm{~d})$.

NIS $(3.5 \mathrm{mg} / \mathrm{kg})$, GBR $(7.5 \mathrm{mg} / \mathrm{kg})$, and NIS + GBR all significantly reduced $1 \mathrm{~h}$ food intake in obese mice (Figure 8d). Two-way ANOVA of food intake for obese mice indicated that there was no significant interaction between NIS and GBR treatments at $1 \mathrm{~h}$ (Figure 8g; $P=0.782$ ) or at any other time points postinjection (data not shown). However, NIS and GBR independently produced significant reductions in food intake up to $8 \mathrm{~h}$ postinjection $(P<0.001$ for both drugs at $1,2,4$, and $8 \mathrm{~h}$; Figure $8 \mathrm{~h}$ ). Food intake returned to baseline $24 \mathrm{~h}$ following drug administrations for all treatment groups in both lean and obese mice.

\section{DISCUSSION}

Here, we have demonstrated that acute treatment with a dual DA and NE reuptake inhibitor (BUP) caused a dosedependent reduction in short-term food intake in hungry mice that was independent of its effects on locomotor activity. Moreover, selective inhibition of either the DA (GBR12783) or NE (NIS) transporter also produced a dosedependent reduction in short-term food intake. These independent effects of NIS and GBR were found to be completely additive when both drugs were coadministered. During subchronic drug administration, GBR and NIS only reduced food intake on day 1 of infusion and the acute additive effect of these compounds on feeding was absent. Instead, subchronic coadministration of NIS and GBR produced an additive reduction in body weight, with an 

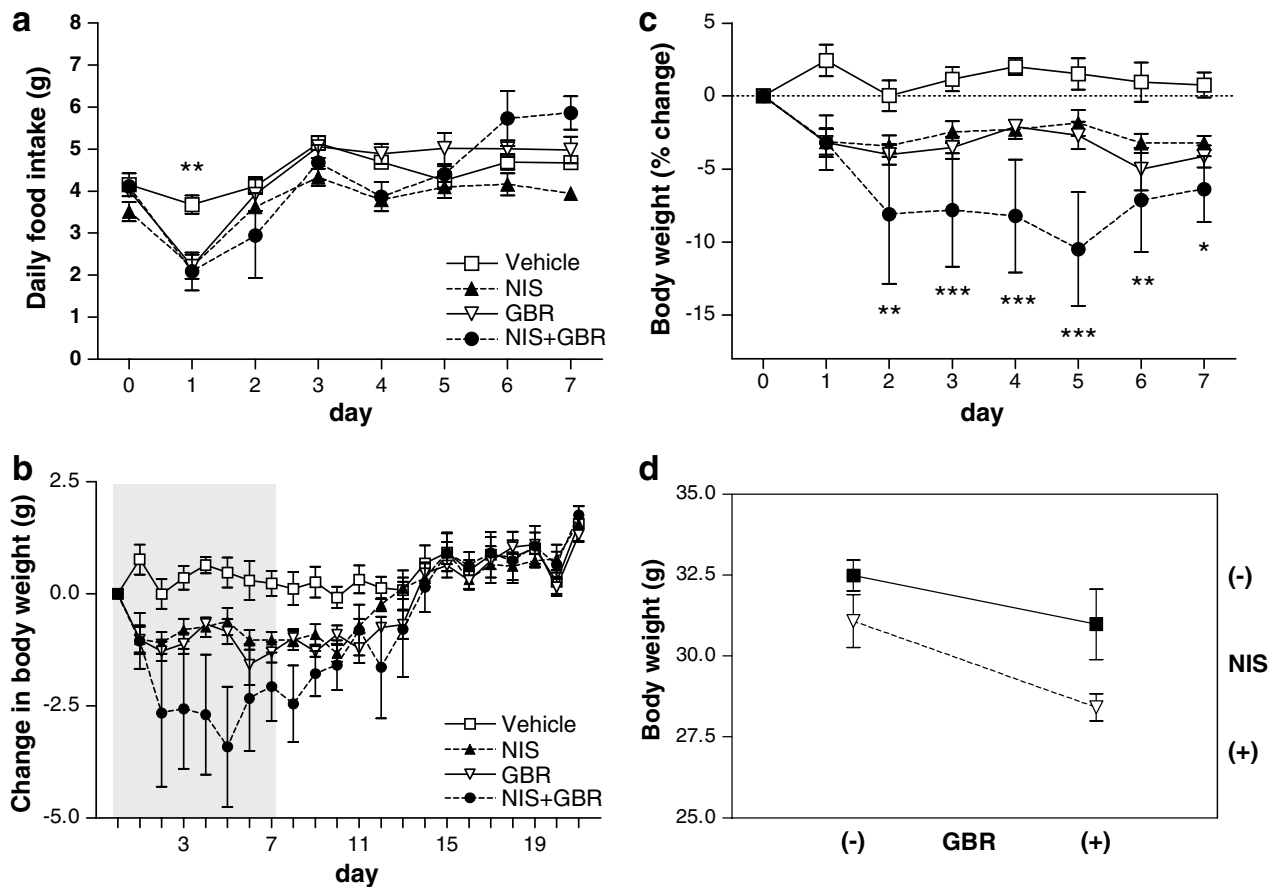

Figure 6 Subchronic DA and NE reuptake inhibition in lean mice produces an additive reduction in body weight without reducing food intake. NIS $(1.5 \mathrm{mg} / \mathrm{kg} / \mathrm{h}), G B R(2.5 \mathrm{mg} / \mathrm{kg} / \mathrm{h})$, or vehicle was infused via mini-osmotic pump that lasted for I week. (a) Daily food intake was significantly reduced from vehicle for all treatment groups only on day I. (b) Change in body weight from preinfusion (average body weight on day $0=32 \mathrm{~g} \pm \mathrm{SEM}$ ). Shaded region indicates duration of drug infusion. (c) \% Change in body weight from day 0 for each animal. NIS + GBR caused a significant reduction in body weight compared to vehicle-treated animals. (d) Two-way ANOVA of body weight on day 5 of infusion reveals no significant interaction $(P>0.05)$. $(* P<0.05$, *** $P<0.0$ I, **** $P<0.00$ I; vehicle, $n=4$; NIS, $n=4$; GBR, $n=4$; NIS + GBR, $n=3$ ).

average weight loss of $8-10 \%$ from control. Finally, the hypophagic effects of BUP, GBR, and NIS on energy balance were preserved in obese mice, as were the additive effects of acute NIS and GBR. These results demonstrate that both DA and NE may contribute to the anorectic effects of BUP and that the hypophagic efficacy of DA and NE reuptake inhibitors is not reduced in obese mice.

A complete isobolographic analysis requires the acquisition of multiple data points using several drug proportions that produce the exact same effect on energy balance, followed by regression analysis (Tallarida, 2001). Two-way ANOVA is a superior (and somewhat more rigorous) method for analysis of drug interactions in behavioral pharmacology because it does not require acquisition of multiple data points and has a simple visual and statistical interpretation of data that can be used to identify significant synergistic or additive effects (Slinker, 1998).

Isobolographic analysis and two-way ANOVA both indicated that GBR and NIS have additive effects on energy balance. The significance of an additive effect is better understood when presented in the context of other drugs that are associated with weight loss. The only FDAapproved centrally acting weight loss drug, sibutramine, inhibits reuptake of both serotonin and NE (Halford, 2006). Sibutramine's efficacy at causing weight loss is probably owing to an additive effect of serotonin and NE on energy balance (Rowland et al, 2001). Other drug combinations have been studied, but failed to produce an additive, let alone synergistic, effect on energy balance (Kaya et al, 2004).
The acute hypophagic effect of BUP presented here is seemingly in contrast to a previous observation in rats where acute oral BUP administration $(10,20$, and $30 \mathrm{mg} / \mathrm{kg}$ per os) did not affect food intake (Liu et al, 2004). There are several explanations for this disparity. First, high doses of BUP are required to produce a reduction in $1 \mathrm{~h}$ food intake. The oral route of administration and low doses administered in the aforementioned experiment were likely insufficient to produce a measurable reduction in food intake. Second, the first feeding measurements were taken $4.5 \mathrm{~h}$ following drug administration. Here, we demonstrate that the inhibitory effect of BUP on feeding is transient- even moderate to high doses of BUP had no effect on food intake $4 \mathrm{~h}$ postinjection. Therefore, feeding measurements taken $4.5 \mathrm{~h}$ following drug administration may have missed a short-term effect of BUP on feeding. Additionally, BUP is metabolized differently in rats and mice; rats do not make significant quantities of the bioactive BUP metabolite, hydroxybupropion (Welch et al, 1987). Hydroxybupropion has a longer half-life than BUP, inhibits both the NE and DA transporters, and also has a functional role as an antidepressant (Martin et al, 1990; Ascher et al, 1995; Bondarev et al, 2003), implying that it may contribute to BUP-induced hypophagia; however, any effects of hydroxybupropion on appetite would not be observed in rats.

In contrast to the anorexigenic effect observed with acute administration, continuous infusion of catecholamine reuptake inhibitors produced a temporary reduction in $24 \mathrm{~h}$ food intake that was absent $48 \mathrm{~h}$ after drug infusion. Despite this short-term effect on feeding, NIS and GBR 

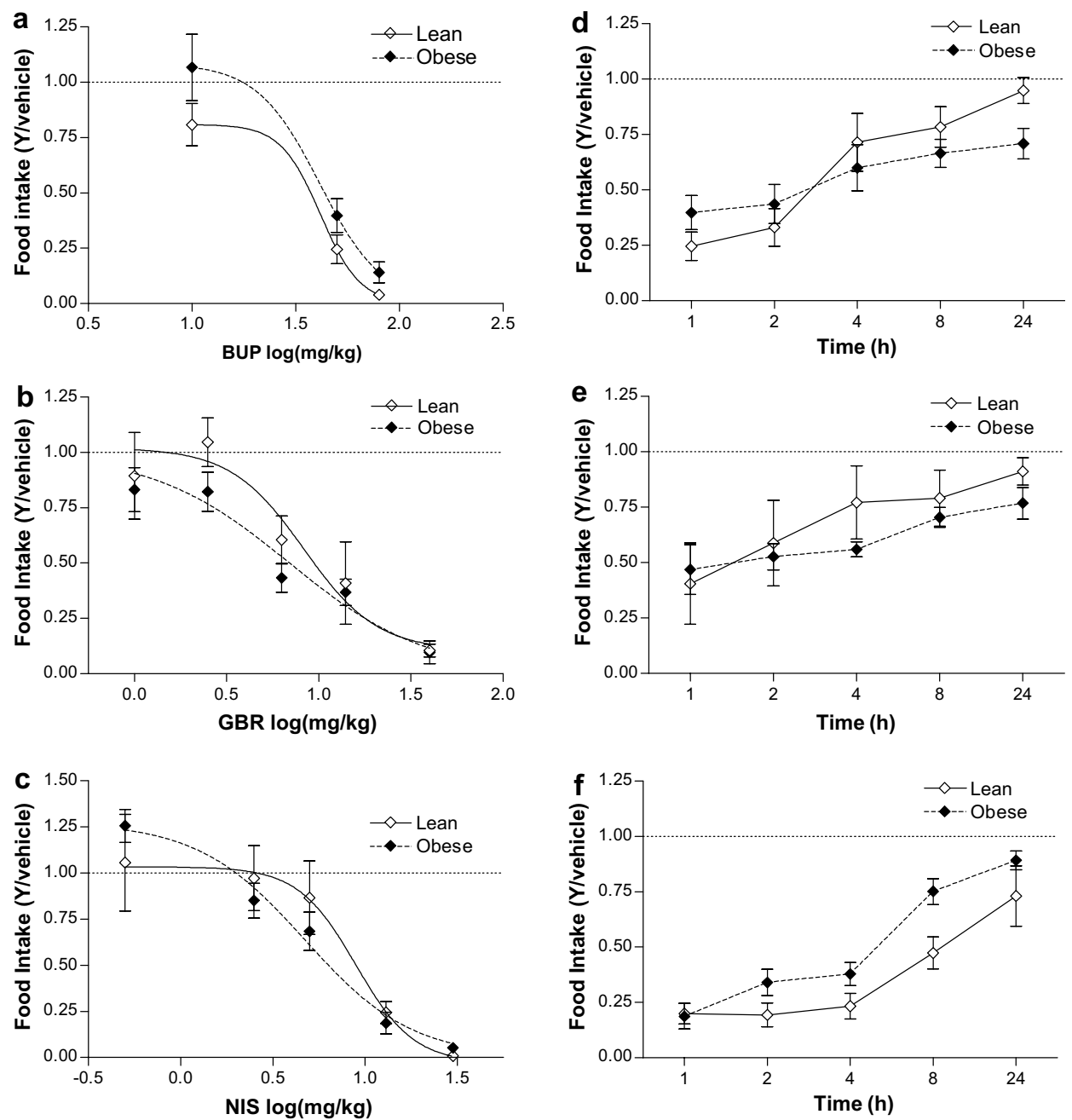

Figure 7 Acute inhibition of DA and NE reuptake produces a dose-dependent reduction in I $\mathrm{h}$ food intake in lean and obese mice on high-fat diet. (a-c) Dose-response curves for reduction in $1 \mathrm{~h}$ food intake in lean and obese mice on a high-fat diet. Data are normalized to vehicle-treated animals. (a) BUP: I0, 50, and $80 \mathrm{mg} / \mathrm{kg}$ i.p. ( $R^{2}=0.86$ for lean and 0.72 for obese mice); (b) GBR: I, 2.5, 6.3, I4, and $40 \mathrm{mg} / \mathrm{kg}$ i.p. ( $R^{2}=0.55$ for lean and 0.53 for obese mice); (c) NIS: $0.5,2.5,5,13$, and $30 \mathrm{mg} / \mathrm{kg}$ i.p. $\left(R^{2}=0.56\right.$ for lean and 0.78 for obese mice); and (d-f) Time course for reduced food intake. Data are normalized to vehicle-treated animals. (d) BUP (50 mg/kg), (e) GBR (14 mg/kg), and (f) NIS (13 mg/kg). (Lean mice, n=5/group; obese mice, $n=7 / g r o u p$.

produced significant independent effects on body weight on days 4 and 5 that were additive and resulted in $2.5-3 \mathrm{~g}$ or $8-10 \%$ weight loss. This finding is consistent with the observation that BUP fails to decrease appetite or daily caloric intake in humans (Harto-Truax et al, 1983), despite its significant effect on body weight. Because daily food intake never differed significantly across treatment groups, the decrease in body weight by NIS and GBR infusion was probably owing to increased energy expenditure. There is substantial evidence that BUP increases energy expenditure in rodents (Liu et al, 2004; Hasegawa et al, 2005) and, consistent with the acute effect of BUP on locomotor activity, this effect may not require activation of peripheral $\beta_{3}$-adrenoceptors in brown adipose tissue (Liu et al, 2004). Whether weight loss in lean mice was owing to a loss in lean or fat mass was not studied, but merits further investigation. If inhibition of DA and NE reuptake causes increased loss of fat mass, then greater weight loss might be expected in obese mice.
In addition to decreasing food intake, acute BUP also dose-dependently increased locomotor activity. This result is consistent with a previous finding that BUP increases locomotor behavior in rodents (Zarrindast and HosseiniNia, 1988) and is similar to the acute effects of psychostimulants, which also cause hyperactivity and hypophagia (Cooper and van der Hoek, 1993). A concurrent effect of BUP on activity and feeding could be owing to interference between hyperactivity and food intake, in which case decreased intake might not be owing to decreased appetite. However, the parallel activity and feeding measurements presented here do not suggest that hypophagia is a byproduct of increased activity because incremental increases in BUP produced independent changes in activity and intake. For example, increasing the BUP dose to $20 \mathrm{mg} /$ $\mathrm{kg}$ significantly decreased food intake from $10 \mathrm{mg} / \mathrm{kg}$, but caused no significant incremental increase in locomotor activity. Likewise, increasing the dose of BUP from 0 to 10 and 20 to $40 \mathrm{mg} / \mathrm{kg}$ increased hyperactivity without 

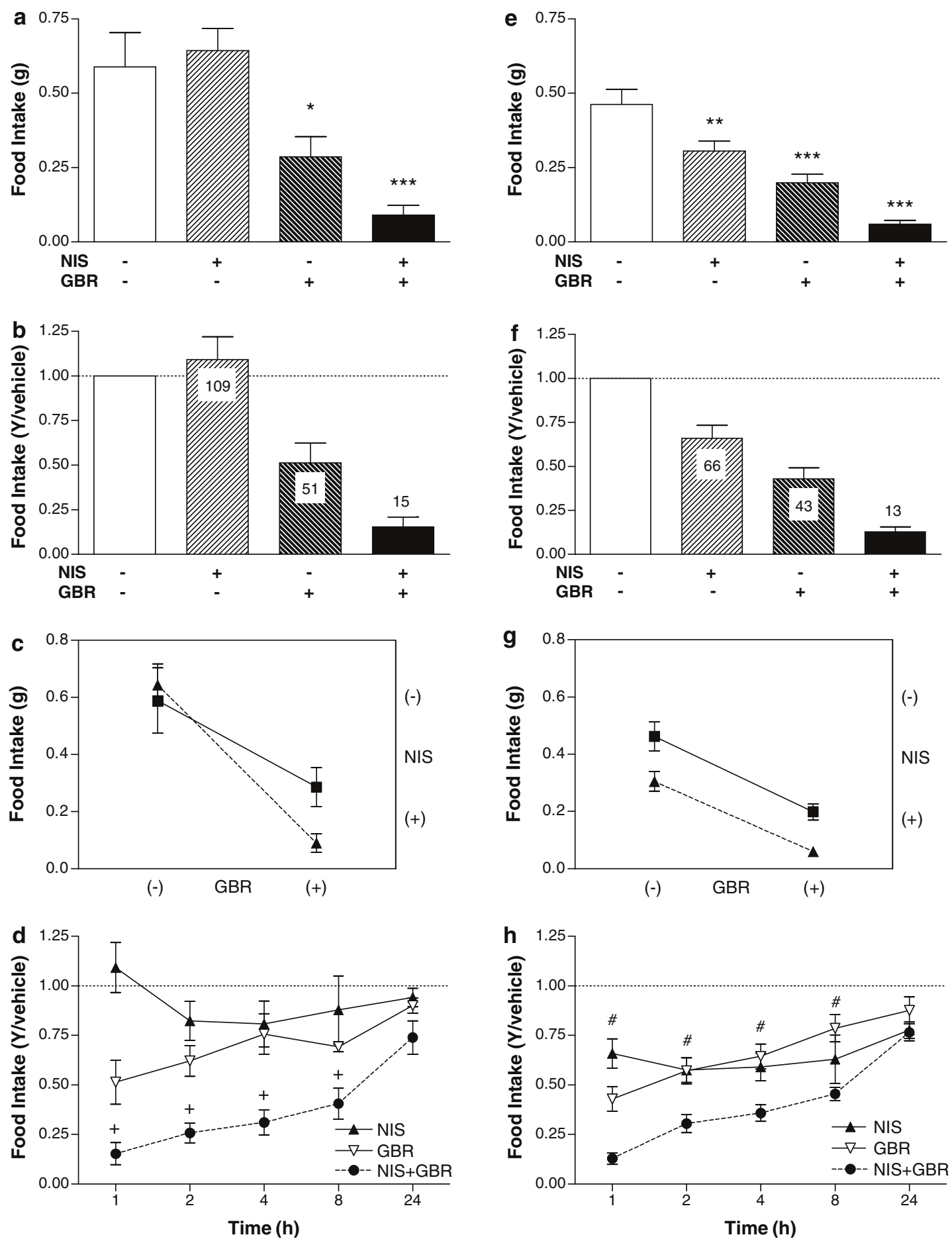

Figure 8 Acute combined inhibition of DA and NE reuptake produces an additive reduction in food intake in lean and obese mice on high-fat diet. (a-d) Sixteen-hour food-deprived lean mice on high-fat diet were injected with NIS (3.5 mg/kg), GBR (7.5 mg/kg), NIS + GBR, or vehicle, and subsequent intake of high-fat diet was recorded ( $n=9 /$ group). (a) One-hour cumulative food intake was reduced significantly compared to vehicle-treated animals in GBR- and NIS + GBR-treated animals. (b) One-hour food intake normalized to control. Numbers indicate \% reduction from vehicle-treated animals. (c) Two-way ANOVA of I h food intake revealed no significant interaction for NIS and GBR at I h $(P>0.05)$, but a significant main effect for GBR ( $P<0.00 \mathrm{I})$. (d) Time course for food intake in drug-treated animals. GBR produced a significant independent reduction in food intake that lasted up to $8 \mathrm{~h}\left({ }^{+} P<0.00 \mathrm{I}\right.$ for I, 2,4 , and $8 \mathrm{~h}$ postinjection). (e-h) Sixteen-hour food-deprived obese mice on high-fat diet were injected with NIS (3.5 mg/kg), GBR (7.5 mg/kg), NIS + GBR, or vehicle, and subsequent intake of high-fat diet was recorded ( $n=15 /$ group). (e) NIS, GBR, and NIS + GBR all decreased I h food intake compared to vehicle. (f) One-hour food intake normalized to control. Numbers indicate \% reduction from vehicle-treated animals. (g) Two-way ANOVA of I h food intake revealed no significant interaction for NIS and GBR $(P>0.05)$, but a significant main effect for both NIS and GBR $(P<0.00 \mathrm{I})$. (h) Time course for food intake in drug-treated animals. At I, 2, 4, and $8 \mathrm{~h}$ postinjection, GBR and NIS produced significant independent reductions in food intake that were additive $\left({ }^{\#} P<0.00\right.$ I for both NIS and GBR). 
significantly increasing hypophagia (Figure 1e). These data suggest a discrete effect of BUP on activity and reinforces an independent effect of BUP on energy balance.

$\mathrm{DA}$ and NE are involved in many brain signaling pathways; however, considerable evidence suggests that altering catecholaminergic signaling will affect food intake and body weight through classic hypothalamic systems involved in the regulation of energy balance. The arcuate nucleus of the hypothalamus (ARH) is the primary forebrain sensor of peripheral cues that relay information about energy availability and storage and contains two types of cells that have opposing effects on energy balance. Activation of NPY-expressing cells causes hyperphagia and energy conservation, whereas activation of cells that express pro-opiomelanocortin (POMC) is associated with hypophagia and increased energy expenditure (Cone, 2005). NPY and NE are colocalized in select neurons in the brain and periphery, and ascending neurons from the brainstem corelease NPY and NE (Inenaga et al, 1986). An NE reuptake inhibitor like NIS could potentially cause anorexia by decreasing activity of cells that express NPY and NE. DA receptor activation is also highly correlated with ARH neuropeptide expression. Selective activation of the D2 receptor reduces ARH NPY mRNA and increases POMC mRNA expression, whereas antagonism of the D2 receptor causes the opposite effect (Pelletier and Simard, 1991; Tong and Pelletier, 1992). Increased extracellular DA (caused by inhibition of the DA reuptake transporter) could account for part of the hypophagic and thermogenic effects of BUP. Such an idea is supported by evidence that D1/D2 receptor blockade significantly attenuates BUP-induced thermogenesis (Liu et al, 2004).

Instead of reducing appetite, DA and/or NE reuptake inhibition could induce nausea and supersede hunger caused by short-term food deprivation. We have not directly assessed the ability of BUP, GBR, or NIS to produce conditioned taste aversion, but considerable evidence suggests that these drugs do not induce illness. Although nausea is one of the adverse events associated with BUP treatment in humans (occurring in more than $5 \%$ of subjects), the low percentage of subjects that discontinue treatment (7-11\%, depending on dosing, $v s 4 \%$ for placebo) supports favorable tolerability of BUP in humans (Settle et al, 1999). Additionally, $\mathrm{DA}, \mathrm{NE}$, and/or serotonin reuptake inhibitors are commonly prescribed in the treatment of mood disorders and are generally well tolerated (Scates and Doraiswamy, 2000; Simpson and Plosker, 2004), and psychostimulants that affect NE and DA reuptake (like amphetamine and cocaine) also suppress appetite without inducing illness (Wellman, 2005). Finally, results from subchronic NIS and GBR infusions suggest that continuous inhibition of DA and NE reuptake has a prolonged effect on body weight, but only a transient effect on appetite. The lack of a sustained effect of NE and DA reuptake inhibitors on daily food intake during subchronic drug administration is inconsistent with the notion that these drugs reduce food intake by causing nausea.

There are reports that chronic obesity can lead to changes in catecholamine turnover (Levin et al, 1986; Wang et al, 2002) and several studies have demonstrated that expression of brain D1 and D2 receptors is altered in obese humans (Wang et al, 2002) and obese mice and rats
(Fetissov et al, 2002; Huang et al, 2005). However, these changes do not appear to reduce the hypophagic effects of catecholamine reuptake inhibitors - our results indicate that BUP, GBR, and NIS all cause dose-dependent hypophagia in obese mice. These findings are supported by the efficacy of BUP in reducing body weight in obese humans (Gadde et al, 2001; Anderson et al, 2002; Jain et al, 2002) and validate the need for further research on the effects of catecholamine reuptake inhibitors on energy balance in both lean and obese animal models.

The availability of highly palatable food increases rewardbased or hedonic feeding in humans and animals (Saper et al, 2002). Although NIS did not independently reduce food intake in lean mice on a high-fat diet, it appeared to potentiate the significant inhibitory effect of GBR. This result implies that catecholamine reuptake inhibitors not only decrease standard chow intake but also decrease intake of a more palatable and rewarding high-fat diet. This idea is consistent with the involvement of DA in mediating both incentive motivation and the rewarding effects of reinforcing stimuli (such as palatable food) (Wise, 2004). Considering the vast availability of highly palatable food in developed countries, the ability of a DA and NE reuptake inhibitors to over-ride potential hedonically driven aspects of feeding behavior is especially applicable to humans (Wang et al, 2002).

Successful obesity treatments will likely require combination therapy that targets multiple systems that contribute to regulation of energy homeostasis (Horvath, 2005). Evidence that the NET is able to take up DA (Millan et al, 2000) and that adrenergic receptors are able to modulate dopaminergic cell firing rate (Paladini and Williams, 2004) suggests that there is a significant amount of interplay between catecholaminergic systems. Because DA and $\mathrm{NE}$ are two predominant neurotransmitters in the brain that are intimately involved in the regulation of energy balance (Wellman, 2005), the sustained effect of BUP on body weight is likely owing to BUP's action as a dual DA and NE reuptake inhibitor. This study demonstrates that selective and combined DA and NE reuptake inhibition reduces food intake and body weight in lean and obese mice. Furthermore, we provide evidence that DA and NE reuptake inhibitors produce independent additive effects on energy balance that may contribute to the anorectic effect of BUP.

\section{ACKNOWLEDGEMENTS}

We thank Dr Kevin L Grove for his helpful discussion and advice on this manuscript, as well as Aaron Eusterbrock and Luciana $\mathrm{T}$ Lemos for technical assistance. This work was supported by grants from the National Institutes of Health (RR0163 and DK62202).

\section{REFERENCES}

Anderson JW, Greenway FL, Fujioka K, Gadde KM, McKenney J, O’Neil PM (2002). Bupropion SR enhances weight loss: a 48-week double-blind, placebo-controlled trial. Obes Res 10: 633-641.

Ascher JA, Cole JO, Colin JN, Feighner JP, Ferris RM, Fibiger HC et al (1995). Bupropion: a review of its mechanism of antidepressant activity. J Clin Psychiatry 56: 395-401. 
Bina KG, Cincotta AH (2000). Dopaminergic agonists normalize elevated hypothalamic neuropeptide $\mathrm{Y}$ and corticotropin-releasing hormone, body weight gain, and hyperglycemia in ob/ob mice. Neuroendocrinology 71: 68-78.

Bondarev ML, Bondareva TS, Young R, Glennon RA (2003). Behavioral and biochemical investigations of bupropion metabolites. Eur J Pharmacol 474: 85-93.

Bonnet JJ, Costentin J (1986). GBR 12783, a potent and selective inhibitor of dopamine uptake: biochemical studies in vivo and ex vivo. Eur J Pharmacol 121: 199-209.

Cheetham SC, Viggers JA, Butler SA, Prow MR, Heal DJ (1996). $\left[{ }^{3} \mathrm{H}\right]$ nisoxetine - a radioligand for noradrenaline reuptake sites: correlation with inhibition of $\left[{ }^{3} \mathrm{H}\right]$ noradrenaline uptake and effect of DSP-4 lesioning and antidepressant treatments. Neuropharmacology 35: 63-70.

Cone RD (2005). Anatomy and regulation of the central melanocortin system. Nat Neurosci 8: 571-578.

Cooper SJ, van der Hoek GA (1993). Cocaine: a microstructural analysis of its effects on feeding and associated behaviour in the rat. Brain Res 608: 45-51.

Davidson J (1989). Seizures and bupropion: a review. J Clin Psychiatry 50: 256-261.

Eisenhofer G (2001). The role of neuronal and extraneuronal plasma membrane transporters in the inactivation of peripheral catecholamines. Pharmacol Ther 91: 35-62.

Fetissov SO, Meguid MM, Sato T, Zhang LH (2002). Expression of dopaminergic receptors in the hypothalamus of lean and obese Zucker rats and food intake. Am J Physiol Regul Integr Comp Physiol 283: R905-R910.

Gadde KM, Parker CB, Maner LG, Wagner II HR, Logue EJ, Drezner MK et al (2001). Bupropion for weight loss: an investigation of efficacy and tolerability in overweight and obese women. Obes Res 9: 544-551.

Halford JC (2006). Pharmacotherapy for obesity. Appetite 46: 6-10. Harto-Truax N, Stern WC, Miller LL, Sato TL, Cato AE (1983). Effects of bupropion on body weight. J Clin Psychiatry 44: 183-186.

Hasegawa H, Meeusen R, Sarre S, Diltoer M, Piacentini MF, Michotte Y (2005). Acute dopamine/noradrenaline reuptake inhibition increases brain and core temperature in rats. J Appl Physiol 99: 1397-1401.

Hoffman BB (2001). Catecholamines, sympathomimetic drugs, and adrenergic receptor antagonists. In: Hardman JG, Limbird LE, Goodman Gilman A (eds). Goodman \& Gilman's The Pharmacological Bases of Therapeutics. McGraw-Hill: New York. pp 215-268.

Horvath TL (2005). The hardship of obesity: a soft-wired hypothalamus. Nat Neurosci 8: 561-565.

Huang XF, Yu Y, Zavitsanou K, Han M, Storlien L (2005). Differential expression of dopamine D2 and D4 receptor and tyrosine hydroxylase mRNA in mice prone, or resistant, to chronic high-fat diet-induced obesity. Brain Res Mol Brain Res 135: $150-161$.

Hughes JR, Stead LF, Lancaster T (2004). Antidepressants for smoking cessation. Cochrane Database Syst Rev: CD000031.pub2. DOI:10.1002/14651858.CD000031.pub2.

Inenaga K, Dyball RE, Okuya S, Yamashita H (1986). Characterization of hypothalamic noradrenaline receptors in the supraoptic nucleus and periventricular region of the paraventricular nucleus of mice in vitro. Brain Res 369: 37-47.

Jackson HC, Bearham MC, Hutchins LJ, Mazurkiewicz SE, Needham AM, Heal DJ (1997). Investigation of the mechanisms underlying the hypophagic effects of the 5-HT and noradrenaline reuptake inhibitor, sibutramine, in the rat. $\mathrm{Br}$ J Pharmacol 121: 1613-1618.

Jain AK, Kaplan RA, Gadde KM, Wadden TA, Allison DB, Brewer ER et al (2002). Bupropion SR vs. placebo for weight loss in obese patients with depressive symptoms. Obes Res 10: 1049-1056.
Kaya A, Aydin N, Topsever P, Filiz M, Ozturk A, Dagar A et al (2004). Efficacy of sibutramine, orlistat and combination therapy on short-term weight management in obese patients. Biomed Pharmacother 58: 582-587.

Levin BE, Triscari J, Sullivan AC (1986). The effect of diet and chronic obesity on brain catecholamine turnover in the rat. Pharmacol Biochem Behav 24: 299-304.

Lin S, Thomas TC, Storlien LH, Huang XF (2000). Development of high fat diet-induced obesity and leptin resistance in $\mathrm{C} 57 \mathrm{Bl} / 6 \mathrm{~J}$ mice. Int J Obes Relat Metab Disord 24: 639-646.

Liu YL, Connoley IP, Heal DJ, Stock MJ (2004). Pharmacological characterisation of the thermogenic effect of bupropion. Eur $J$ Pharmacol 498: 219-225.

Martin P, Massol J, Colin JN, Lacomblez L, Puech AJ (1990). Antidepressant profile of bupropion and three metabolites in mice. Pharmacopsychiatry 23: 187-194.

Millan MJ, Lejeune F, Gobert A (2000). Reciprocal autoreceptor and heteroreceptor control of serotonergic, dopaminergic and noradrenergic transmission in the frontal cortex: relevance to the actions of antidepressant agents. J Psychopharmacol 14: $114-138$

Nomikos GG, Damsma G, Wenkstern D, Fibiger HC (1992). Effects of chronic bupropion on interstitial concentrations of dopamine in rat nucleus accumbens and striatum. Neuropsychopharmaco$\log y$ 7: 7-14.

Paladini CA, Robinson S, Morikawa H, Williams JT, Palmiter RD (2003). Dopamine controls the firing pattern of dopamine neurons via a network feedback mechanism. Proc Natl Acad Sci USA 100: 2866-2871.

Paladini CA, Williams JT (2004). Noradrenergic inhibition of midbrain dopamine neurons. J Neurosci 24: 4568-4575.

Pelletier G, Simard J (1991). Dopaminergic regulation of preproNPY mRNA levels in the rat arcuate nucleus. Neurosci Lett 127: $96-98$.

Rowland NE, Lo J, Robertson K (2001). Acute anorectic effect of single and combined drugs in mice using a non-deprivation protocol. Psychopharmacology (Berlin) 157: 193-196.

Saper CB, Chou TC, Elmquist JK (2002). The need to feed: homeostatic and hedonic control of eating. Neuron 36: 199-211.

Scates AC, Doraiswamy PM (2000). Reboxetine: a selective norepinephrine reuptake inhibitor for the treatment of depression. Ann Pharmacother 34: 1302-1312.

Settle EC, Stahl SM, Batey SR, Johnston JA, Ascher JA (1999). Safety profile of sustained-release bupropion in depression: results of three clinical trials. Clin Ther 21: 454-463.

Simpson D, Plosker GL (2004). Atomoxetine: a review of its use in adults with attention deficit hyperactivity disorder. Drugs 64: 205-222.

Slinker BK (1998). The statistics of synergism. J Mol Cell Cardiol 30: $723-731$.

Stahl SM, Pradko JF, Haight BR, Modell JG, Rockett CB, Learned-Coughlin S (2004). A review of the neuropharmacology of bupropion, a dual norepinephrine and dopamine reuptake inhibitor. Prim Care Companion J Clin Psychiatry 6: 159-166.

Tallarida RJ (2001). Drug synergism: its detection and applications. $J$ Pharmacol Exp Ther 298: 865-872.

Thomas SA, Palmiter RD (1997). Disruption of the dopamine betahydroxylase gene in mice suggests roles for norepinephrine in motor function, learning, and memory. Behav Neurosci 111: 579-589.

Tong Y, Pelletier G (1992). Role of dopamine in the regulation of proopiomelanocortin (POMC) mRNA levels in the arcuate nucleus and pituitary gland of the female rat as studied by in situ hybridization. Brain Res Mol Brain Res 15: 27-32.

Wang GJ, Volkow ND, Fowler JS (2002). The role of dopamine in motivation for food in humans: implications for obesity. Expert Opin Ther Targets 6: 601-609. 
Welch RM, Lai AA, Schroeder DH (1987). Pharmacological significance of the species differences in bupropion metabolism. Xenobiotica 17: 287-298.

Wellman PJ (2005). Modulation of eating by central catecholamine systems. Curr Drug Targets 6: 191-199.

Wessinger WD (1986). Approaches to the study of drug interactions in behavioral pharmacology. Neurosci Biobehav Rev 10: 103-113. Wise RA (2004). Dopamine, learning and motivation. Nat Rev Neurosci 5: 483-494.
Yang ZJ, Meguid MM, Chai JK, Chen C, Oler A (1997). Bilateral hypothalamic dopamine infusion in male Zucker rat suppresses feeding due to reduced meal size. Pharmacol Biochem Behav 58: 631-635.

Zarrindast MR, Hosseini-Nia T (1988). Anorectic and behavioural effects of bupropion. Gen Pharmacol 19: 201-204.

Zhou QY, Palmiter RD (1995). Dopamine-deficient mice are severely hypoactive, adipsic, and aphagic. Cell 83: 11971209. 